\title{
Evaluating the electrochemical and photoelectrochemical production of hydroxyl radical during electrocoagulation process
}

\begin{abstract}
Alejandro Medel a,**, José A. Ramírez a, Jesús Cárdenas a , Ignasi Sirés b, Yunny Meas ${ }^{\mathrm{a}, *}$

${ }^{a}$ Centro de Investigación y Desarrollo Tecnológico en Electroquímica, S. C., Parque Tecnológico Querétaro-Sanfandila, C. P. 76703, Pedro Escobedo, Estado de Querétaro, Mexico

${ }^{b}$ Laboratori d'Electroquímica dels Materials i del Medi Ambient, Departament de Química Física, Facultat de Química, Universitat de Barcelona, Martí i Franqués 1-11, 08028 Barcelona, Spain
\end{abstract}

$\begin{aligned} \text { Corresponding author: } & * \text { yunnymeas@cideteq.mx (Y. Meas) } \\ & * * \text { amedel@cideteq.mx (A. Medel) }\end{aligned}$ 


\begin{abstract}
In this study, we evaluate for the first time the effect of ionic composition on the anodic production of hydroxyl radical $\left({ }^{\bullet} \mathrm{OH}_{\mathrm{a}}\right)$ during electrocoagulation (EC) process in batch using carbon steel electrodes. Likewise, hydroxyl radical production from active chlorine $\left({ }^{\bullet} \mathrm{OH}_{\mathrm{ph}}\right)$ electrogenerated in EC photoassisted with UVA $(\lambda=365 \mathrm{~nm})$ and UVC light $(\lambda=$ $254 \mathrm{~nm}$ ) was evaluated using car wash wastewater. Both, ${ }^{\bullet} \mathrm{OH}_{\mathrm{a}}$ and ${ }^{\bullet} \mathrm{OH}$ ph, were analyzed by UV-Vis spectroscopy and fluorescence using coumarin as the probe. Under optimal conditions $\left(j=8 \mathrm{~mA} \mathrm{~cm}{ }^{-2}, 25^{\circ} \mathrm{C}, 15 \mathrm{~min}, 6 \mathrm{rpm}\right)$, turbidity, suspended solids and color were removed by $98.3 \%, 98.7 \%$ and $93.1 \%$, respectively. However, total organic carbon (TOC) abatement only attained $27 \%$. This can be related to the fact that ${ }^{\bullet} \mathrm{OH}_{\mathrm{a}}$ and ${ }^{\bullet} \mathrm{OH}_{\mathrm{ph}}$ were not identified during EC, with or without UV irradiation. Hence, the organic matter is mainly removed by coagulation with $\mathrm{Fe}(\mathrm{OH})_{\mathrm{n}}$ species. Comparative treatment of the same wastewater by electrochemical oxidation (EO) with a $\mathrm{Ti} \mid \mathrm{IrO}_{2}-\mathrm{Ta}_{2} \mathrm{O}_{5}$ anode in the presence of electrogenerated active chlorine and UVC light demonstrated the generation of ${ }^{\bullet} \mathrm{OH}_{\mathrm{ph}}$, thus encouraging the potential coupling of EC with EO.
\end{abstract}

Keywords: Active chlorine; Car wash wastewater; Electro-oxidation; Electrocoagulation; Hydroxyl radical. 


\section{Introduction}

Wastewater from car washes typically contains a high amount of suspended solids, organic matter, and numerous pollutants such as surfactants, oils, grease, hydrocarbons, plasticizers, microorganisms, $P$ - and $N$-compounds, brake dust and heavy metals, which are lethal to humans and aquatic organisms [1-3]. The exact composition depends on the type of automobile, the service requested and the car wash tunnel particularities [4], but most characteristic parameters can reach up to $644 \mathrm{mg} \mathrm{L}^{-1}$ for total dissolved solids (TDS), 5856 mg L ${ }^{-1}$ for total solids (TS), 772 NTU for turbidity, and $1019 \mathrm{mg} \mathrm{L}^{-1}$ for chemical oxygen demand (COD). Salt and oil contents may attain 1.5\%-2.5\% and $84 \mathrm{mg} \mathrm{L}^{-1}$, respectively, and chemicals like hydrofluoric acid, ammonium bifluoride, paint residues, rubber, phosphates, and volatile organic compounds may also accumulate in the resulting wastewater [5]. As a result, this kind of effluent is not biodegradable and some regulations now limit the discharge to $50 \mathrm{mg} \mathrm{L}^{-1} \mathrm{COD}$ [6]. In Queensland, Australia, and some European countries, less than $70 \mathrm{~L}$ of fresh water is allowed for single car wash and a water reclamation percentage is often imposed. In the Netherlands and Scandinavian countries, 60-70 L per car is the maximum allowable fresh water consumption. In turn, a recycle of 80\% carwash effluent is compulsory in Germany and Austria [6]. Therefore, it is very crucial to conduct research to develop more effective wastewater treatment technologies.

Reported methods for car wash wastewater treatment include different physicochemical processes that, though efficient, do not completely solve the problem $[1,2,4,5,7,8-10]$. One the other hand, there exist several wastewater treatment technologies with potential industrial scale-up and ability to transform the pollutants into more innocuous substances, as for example biological processes, chemical Fenton, heterogeneous 
photocatalysis, and electrochemical methods like electrocoagulation (EC) or electrooxidation (EO). Among them, EC is an excellent option, although traditionally it has been considered that this process has a non-destructive nature [11]. The efficiency of EC mainly relies on the production of coagulating agents, as shown in reactions (1)-(3) for iron anodes, which occur in concomitance with cathodic reactions (4) and (5) [12].

$$
\begin{aligned}
& 4 \mathrm{Fe}_{(\mathrm{s})} \rightarrow 4 \mathrm{Fe}^{2+}+8 \mathrm{e}^{-} \\
& 4 \mathrm{Fe}^{2+}+10 \mathrm{H}_{2} \mathrm{O}+\mathrm{O}_{2(\mathrm{aq})} \rightarrow 4 \mathrm{Fe}(\mathrm{OH})_{3(\mathrm{~s})}+8 \mathrm{H}^{+} \\
& \mathrm{Fe}^{2+}+2 \mathrm{OH}^{-} \rightarrow \mathrm{Fe}(\mathrm{OH})_{2(\mathrm{~s})} \\
& 8 \mathrm{H}^{+}+8 \mathrm{e}^{-} \rightarrow 4 \mathrm{H}_{2(\mathrm{~g})} \\
& 2 \mathrm{H}_{2} \mathrm{O}+2 \mathrm{e}^{-} \rightarrow \mathrm{H}_{2(\mathrm{~g})}+2 \mathrm{OH}^{-}
\end{aligned}
$$

Lately, coexistence of predominant adsorption and precipitation mechanisms with multiple secondary reactions such as direct anodic oxidation, chlorine-mediated oxidation and cathodic reduction has been suggested. More rarely, some authors have hypothesized the possible role of ${ }^{\bullet} \mathrm{OH}$-mediated oxidation in EC, which has caused great controversy [13]. Furthermore, the formation of oxidation by-products during the EC treatment of bronopol with iron anodes has been recently reported, allowing the proposal of $\bullet$ production via chemical reaction (6), as follows $[14,15]$ :

$\mathrm{Fe}^{2+}+\mathrm{HClO} \rightarrow \mathrm{Fe}^{3+}+\cdot{ }^{\bullet} \mathrm{OH}+\mathrm{Cl}^{-}$

Likewise, the addition of $1.0 \mathrm{mM} \mathrm{Fe}{ }^{2+}$ during the treatment of Acid Yellow 36 by EO with DSA ${ }^{\circledR}$ in the presence of active chlorine enhanced the mineralization process, which was related to the formation of ${ }^{\bullet} \mathrm{OH}$ from reaction (6), although the existence of this oxidant was not demonstrated [16]. 
The identification of ${ }^{\bullet} \mathrm{OH}$ is thus of major importance to confirm or refute any result attributed to its potential presence. In EC, it is known that sacrificial anodes possess a low overpotential for $\mathrm{O}_{2}$ evolution reaction and hence, a poor ${ }^{\bullet} \mathrm{OH}_{a}$ production from $\mathrm{H}_{2} \mathrm{O}$ oxidation is expected. However, coupling with ultrasounds seems to yield $\bullet^{\bullet} \mathrm{OH}$ [13]. Also, the potential formation of active chlorine species can result in ${ }^{\bullet} \mathrm{OH}_{\mathrm{ph}}$ formation when the solution is irradiated with UVC light $(\lambda=254 \mathrm{~nm}$ ) during photoassisted EC process (PEC) [17], as shown in reactions (7) and (8). This is not surprising, since the UV/chlorine process is widely described $[18,19]$.

$$
\begin{aligned}
& \mathrm{ClO}^{-}+h v \rightarrow \mathrm{O}^{\bullet-}+\mathrm{Cl}^{\bullet} \\
& \mathrm{O}^{\bullet-}+\mathrm{H}_{2} \mathrm{O} \rightarrow \mathrm{OH}^{-}+{ }^{\bullet} \mathrm{OH}_{\mathrm{ph}}
\end{aligned}
$$

EC with $\mathrm{Al}$ or $\mathrm{Fe}$ anodes does not show great ability to promote active chlorine production, even when the treated solution contains a high amount of chloride ion. Nonetheless, some authors defend this possibility and, in some case, trace amounts have been reported [17]. Therefore, it is necessary to evaluate with detail whether coupling EC with UV light of different wavelength has a direct impact on ${ }^{\bullet} \mathrm{OH}$ and ${ }^{\bullet} \mathrm{OH}_{\mathrm{ph}}$ production according to reactions (6)-(8).

Several studies on car wash wastewater treatment have been reported so far, focused on chemical Fenton and photo-Fenton [20,21], single EC [22,23], and EC followed by EO with $\mathrm{PbO}_{2}$ and or boron-doped diamond (BDD) anode [4,24]. Coupling between EC (Al electrodes, $\left.\mathrm{pH} 7, j=150 \mathrm{~A} \mathrm{~m}^{-2}, 60 \mathrm{~min}\right)$ and EO (BDD anode, $\mathrm{pH} 8, j=210 \mathrm{~A} \mathrm{~m}^{-2}, 120$ min) allowed $\geq 96 \%$ removal of oils, color, turbidity and COD at the end of the combined treatment [24]. Our groups have wide experience in manufacturing industrial prototypes based on electrochemical processes, including EC [11]. Based on the advantages that EC 
offers to treat toxic effluents with high organic matter contents, the present study investigates in detail the production of ${ }^{\bullet} \mathrm{OH}_{\mathrm{a}}$ from anodic oxidation of water and ${ }^{\bullet} \mathrm{OH}_{\mathrm{ph}}$ from electrogenerated active chlorine with UV photoassistance, and the potential impact of these oxidants during the treatment of car wash wastewater by EC with iron-based electrodes.

\section{Materials and methods}

\subsection{Chemicals}

When needed, the solution $\mathrm{pH}$ was adjusted with $\mathrm{H}_{2} \mathrm{SO}_{4}$ or $\mathrm{HCl}$ (Faga Lab). Coumarin $\left(\mathrm{C}_{9} \mathrm{H}_{6} \mathrm{O}_{2}\right.$, Sigma-Aldrich) was used as the probe compound for the analysis of ${ }^{\bullet} \mathrm{OH}_{\mathrm{a}}$ and ${ }^{\bullet} \mathrm{OH}_{\mathrm{ph}}$. All synthetic solutions were prepared with water from a Millipore Milli-Q system ( $\rho=18.2 \mathrm{M} \Omega . \mathrm{cm}$ at $25{ }^{\circ} \mathrm{C}$, electrical conductivity of $0.0549 \mu \mathrm{S} \mathrm{cm}{ }^{-1}$ and $7 \mu \mathrm{g} \mathrm{L}^{-1}$ of total organic carbon (TOC)).

\subsection{Wastewater characterization}

A plastic bin was filled with $20 \mathrm{~L}$ of car wash wastewater obtained from a client and immediately refrigerated at $4{ }^{\circ} \mathrm{C}$. To run each trial, sampling from that bin was made after vigorous stirring to ensure homogeneity. The $\mathrm{pH}$ and electrical conductivity $(K)$ analysis was performed at $25^{\circ} \mathrm{C}$, using a Thermo Scientific Orion Star A215 pH and conductivity benchtop meter. The redox potential was measured on a Hach HQ40D portable multimeter equipped with an Intellical ORP probe. Fluorescence analysis of colloidal organic matter was carried out considering the homogeneity and stability of the samples. To quantify the potentially toxic elements (PTEs), $40 \mathrm{~mL}$ of raw wastewater were digested with $\mathrm{HNO}_{3}: \mathrm{HCl}(4: 1$, v/v), using an Anton Paar Multiwave 
Pro microwave oven, at $800 \mathrm{~W}$ and $240{ }^{\circ} \mathrm{C}$. The analysis was then made using an Agilent 4100 microwave plasma atomic emission spectrometer (MP-AES). Ion chromatography was performed on a Dionex ICS-2500 high performance liquid chromatograph equipped with an ED50A conductivity detector and coupled with a Dionex IonPac AS14A column. The analysis was carried out according to EPA Method 300.1 (EPA, 1997), eluting a $\mathrm{Na}_{2} \mathrm{CO}_{3} / \mathrm{NaHCO}_{3}$ mixture as the solvent at $1 \mathrm{~mL}$ $\min ^{-1}$. The quality of the results was evaluated using the IC-FAS-1A certified standard analysis from Inorganic Ventures. Color, turbidity and total suspended solids (TSS) were determined with a DR900 multiparameter portable colorimeter from Hach, with limits of detection of 6 FAU, $4 \mathrm{mg} \mathrm{L}^{-1}$ and 15 units, respectively. UV-Vis and fluorescence measurements were made using an Agilent 8453 spectrophotometer and a Cary Eclipse fluorescence spectrophotometer, respectively. TOC, inorganic carbon (IC) and total nitrogen (TN) analyses were performed on a Shimadzu TOC-VCSN.

Table 1 summarizes the concentration of metallic cations, with detection limits of 1-6 $\mu g \mathrm{~L}^{-1}$, showing a significant concentration of $\mathrm{Mg}$ and $\mathrm{Ca}$. The identification of these two elements is important, since they embed on the cathode in the absence of polarity reversal during the electrochemical treatment, which can be minimized when chloride ion is present. Toxic elements like $\mathrm{Pb}$ and $\mathrm{Cr}$ were found at concentrations of 0.07 and $0.01 \mathrm{mg} \mathrm{L}^{-1}$, below the maximum permissible limits [25], whereas $\mathrm{Cd}$ and $\mathrm{Zn}$ remained under the limit of quantification (LOQ) with 1.4 and $3.1 \mu \mathrm{g} \mathrm{L}^{-1}$, respectively.

Table 1. Analysis of potentially toxic elements (PTEs) in wastewater by MP-AES.

\begin{tabular}{lllllllll}
\hline \multicolumn{10}{c}{ PTE $\left(\mathrm{mg} \mathrm{L}^{-1}\right)$} \\
\hline $\mathrm{Pb}$ & $\mathrm{Cu}$ & $\mathrm{Fe}$ & $\mathrm{Mg}$ & $\mathrm{Ca}$ & $\mathrm{Al}$ & $\mathrm{Ni}$ & $\mathrm{Co}$ & $\mathrm{Cr}$ \\
0.07 & 0.03 & 6.49 & 34.47 & 48.20 & 4.46 & 0.08 & 0.05 & 0.01 \\
\hline
\end{tabular}


Table 2 shows the anionic content, being evident the presence of $\mathrm{Cl}^{-}$and $\mathrm{SO}_{4}{ }^{2-}$, along with $\mathrm{F}^{-}$and $\mathrm{NO}_{3}{ }^{-}$at much lower concentration. The two former anions are especially important regarding the performance of many electrochemical processes [26]. In particular, chloride may be transformed into active chlorine $\left(\mathrm{Cl}_{2}, \mathrm{ClO}^{-}\right.$or $\left.\mathrm{HClO}\right)$ via reactions (9)-(12) that depend on both, solution $\mathrm{pH}$ and electrocatalytic activity of the anode. Anions such as $\mathrm{NO}_{2}{ }^{-}, \mathrm{Br}^{--}$and $\mathrm{PO}_{4}{ }^{3-}$ remained under the LOQ.

Table 2. Analysis of inorganic ions in wastewater by ion chromatography.

\begin{tabular}{|c|c|c|c|c|c|c|}
\hline \multicolumn{7}{|c|}{ Anion (mg L-1) } \\
\hline$\overline{\mathrm{F}^{-}}$ & $\mathrm{Cl}^{-}$ & $\mathrm{NO}_{2}^{-}$ & $\mathrm{Br}^{-}$ & $\mathrm{NO}_{3}^{-}$ & $\mathrm{PO}_{4}^{3-}$ & $\mathrm{SO}_{4}^{2-}$ \\
\hline 1.19 & 651.0 & $<0.25$ & $<0.25$ & 3.60 & $<0.50$ & 725.0 \\
\hline \multicolumn{6}{|c|}{$\mathrm{Cl}^{-}+2 \mathrm{OH}^{-} \rightarrow \mathrm{ClO}^{-}+\mathrm{H}_{2} \mathrm{O}+2 \mathrm{e}^{-}$} & (9) \\
\hline \multicolumn{6}{|c|}{$\mathrm{Cl}^{-} \rightarrow \mathrm{Cl}_{2(\mathrm{aq})}+2 \mathrm{e}^{-}$} & (10) \\
\hline \multicolumn{6}{|c|}{$\mathrm{Cl}_{2}+\mathrm{H}_{2} \mathrm{O} \rightarrow \mathrm{HClO}+\mathrm{H}^{+}+\mathrm{Cl}^{-}$} & (11) \\
\hline \multicolumn{6}{|c|}{$\mathrm{HClO} \leftrightarrows \mathrm{H}^{+}+\mathrm{ClO}^{-}$} & (12) \\
\hline
\end{tabular}

A complete physicochemical characterization of the real wastewater is presented in Table 3. 
Table 3. Physicochemical characterization of the raw car wash wastewater, and change of each parameter during EC trials carried out in an undivided electrochemical cell at natural $\mathrm{pH}(8.4)$ and $25^{\circ} \mathrm{C}$, without addition of supporting electrolyte, at different current densities (j) for $15 \mathrm{~min}$. Solutions were stirred with a magnetic bar at $6 \mathrm{rpm}$.

\begin{tabular}{|c|c|c|c|c|c|c|}
\hline \multirow[t]{2}{*}{ Parameter } & \multicolumn{6}{|c|}{$j\left(\mathrm{~mA} \mathrm{~cm}^{-2}\right)$} \\
\hline & 0 & 3 & 7 & 8 & 9 & 10 \\
\hline Turbidity (FAU) & 366.2 & 15 & 6 & 6 & 14 & 12 \\
\hline \% Removal & - & 95.9 & 98.3 & 98.3 & 96.1 & 96.7 \\
\hline TSS $\left(\mathrm{mg} \mathrm{L}^{-1}\right)$ & 356 & 12 & 4 & 4.6 & 11 & 9 \\
\hline$\%$ Removal & - & 96.6 & 98.8 & 98.7 & 96.9 & 97.4 \\
\hline Color (Pt-Co) & $>1000$ & 210 & 74 & 69 & 127 & 136 \\
\hline \% Removal & - & 79.0 & 92.6 & 93.1 & 87.3 & 86.4 \\
\hline TOC $\left(\mathrm{mg} \mathrm{L}^{-1}\right)$ & 127.2 & 119.6 & 113.6 & 91.6 & 83.4 & 81.0 \\
\hline \% Removal & - & 5.9 & 10.6 & 27.9 & 34.4 & 36.2 \\
\hline IC $\left(\mathrm{mg} \mathrm{L}^{-1}\right)$ & 124.1 & 99.4 & 109.8 & 98.6 & 107.1 & 110.5 \\
\hline \% Removal & - & 19.8 & 11.5 & 20.4 & 13.6 & 10.9 \\
\hline $\mathrm{TN}\left(\mathrm{mg} \mathrm{L}^{-1}\right)$ & 110.3 & 107.1 & 71.8 & 109.5 & 67.7 & 78.1 \\
\hline \% Removal & - & 2.90 & 34.8 & 0.7 & 38.6 & 29.1 \\
\hline $\mathrm{pH}$ & 8.4 & 8.3 & 8.4 & 8.4 & 8.4 & 8.4 \\
\hline$\left.K(\mathrm{mS} \mathrm{cm})^{-1}\right)$ & 3.53 & 3.5 & 3.5 & 3.6 & 3.5 & 3.5 \\
\hline ORP (mV) & 42.3 & 172.0 & 166.3 & 179.4 & 175.4 & 174.3 \\
\hline
\end{tabular}




\subsection{Electrochemical treatments}

Before performing the EC trials, the carbon steel plates (provided by CIDETEQ) used as sacrificial anodes were subjected to a surface activation process in $0.5 \mathrm{M} \mathrm{H}_{2} \mathrm{SO}_{4}$. For this, a solution of $80 \mathrm{~mL}$ was electrolyzed in an undivided cell at $25{ }^{\circ} \mathrm{C}$ and $j=8 \mathrm{~mA} \mathrm{~cm}{ }^{-2}$, with constant stirring at 6 rpm provided by a magnetic stirrer from Corning, for 60 min. The geometrically active area of the two carbon steel plates used as the anode and cathode, with an interelectrode gap of $0.9 \mathrm{~cm}$, was $9.34 \mathrm{~cm}^{-2}$. The temperature of the treated solution was controlled during the electrolysis using a PolyScience water bath. Fig. 1 shows the experimental setup.

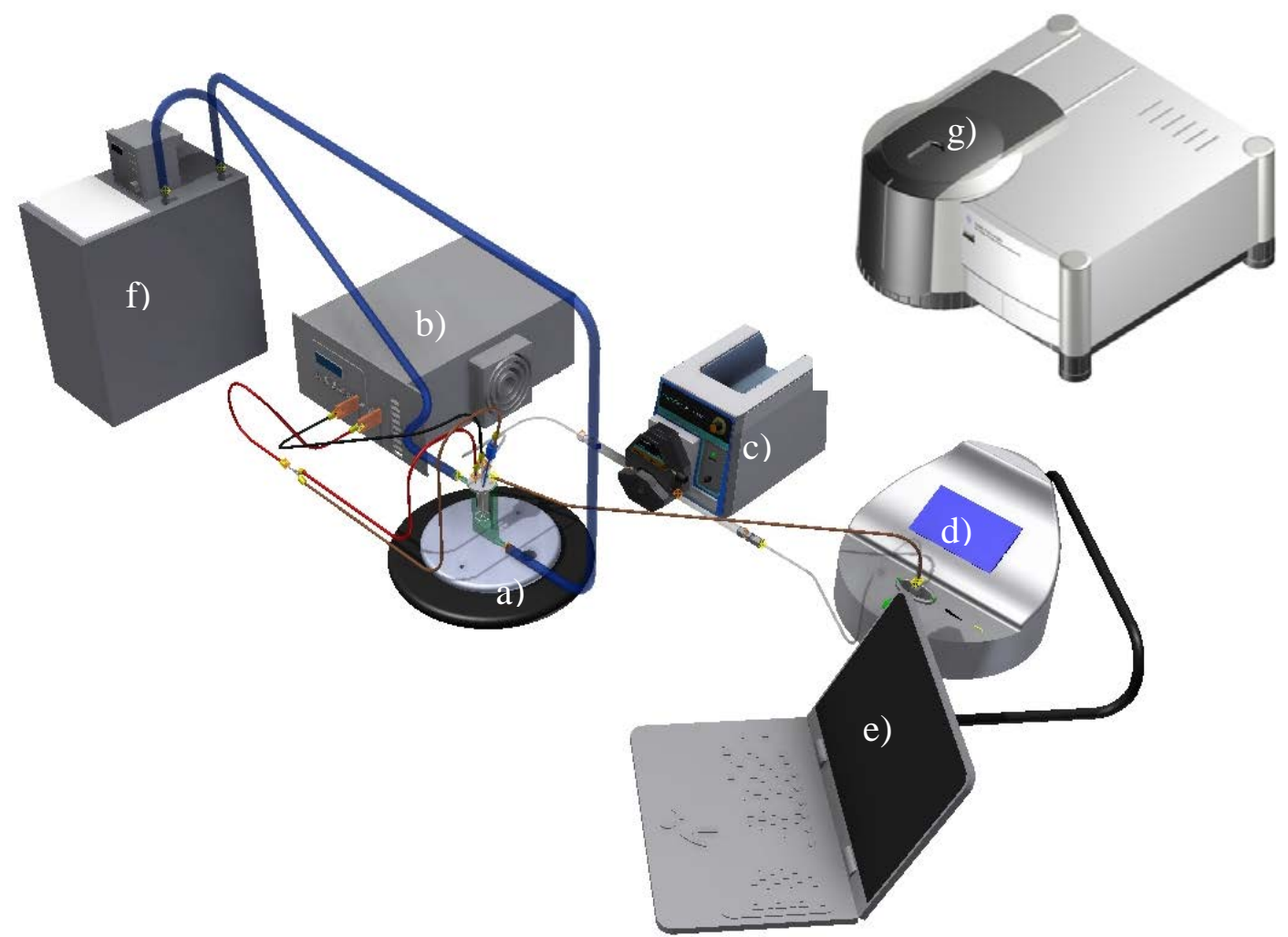

Fig. 1. Experimental setup used for all the electrolytic experiments, including the equipment for the analysis of ${ }^{\bullet} \mathrm{OH}_{\mathrm{a}}$ and ${ }^{\bullet} \mathrm{OH}_{\mathrm{ph}}$ in situ. (a) Undivided electrochemical cell; (b) power supply; (c) peristaltic pump; (d) UV-Vis spectrophotometer; (e) data acquisition equipment; (f) water bath; and (g) fluorescence spectrophotometer. 
Once concluded, the electrodes were withdrawn from the electrochemical cell and rinsed with ultrapure water. Both electrodes were immersed in an ultrasonic bath for 20 min and were then rinsed with water. Afterwards, different EC experiments were performed during specific time intervals. All the electrolyses were performed at constant current using LKB Bromma power supply.

During the activation process, detachment of black impurities from the anode was clearly observed. To evaluate the structural and morphological changes occurred on the electrode surface upon electrochemical polarization, scanning electron microscopy (SEM) and energy dispersive X-ray analysis (EDX) were employed. Typical conditions for this type of analysis have been reported elsewhere [27]. Fig. 2 shows the initial and final SEM images of the carbon steel plate, revealing evident changes in both, morphology and composition. The Fe content increased up to 78.12 at.\% during the activation process, demonstrating the great effectiveness of the surface activation pre-treatment.

The EC experiments with the car wash wastewater were performed using the same experimental procedure described for the activation (see setup in Fig. 1). After each run, samples were withdrawn and filtered with a syringe to perform the different analyses. In experiments with UVA $(\lambda=365 \mathrm{~nm})$ and UVC $(\lambda=254 \mathrm{~nm})$ light irradiation, a $6-\mathrm{W}$ UVGL-58 Handheld UV lamp was placed above the solution, at $5 \mathrm{~cm}$. 

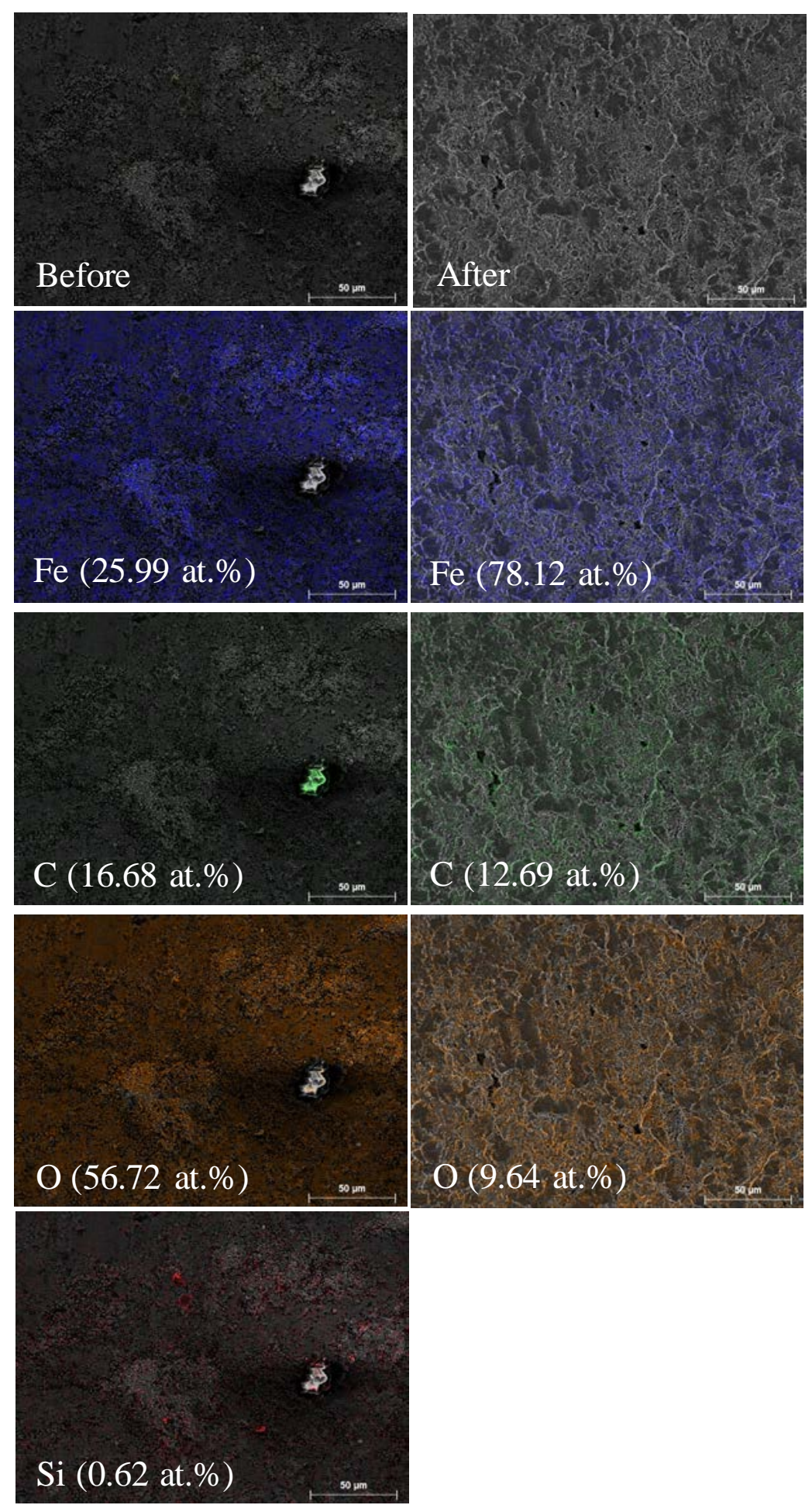

Fig. 2. Analysis of carbon steel anode, subjected to electrochemical activation pretreatment, by SEM-EDX. Electrolytic conditions: $80 \mathrm{~mL}$ of $0.5 \mathrm{M} \mathrm{H}_{2} \mathrm{SO}_{4}$ electrolyzed in an undivided at $25^{\circ} \mathrm{C}$ and constant current of $75 \mathrm{~mA}$, with constant stirring at $6 \mathrm{rpm}$ for 60 $\min$. 


\subsection{Determination of hydroxyl radicals}

For the analysis of hydroxyl radicals formed via electrochemical oxidation $\left({ }^{\bullet} \mathrm{OH}_{\mathrm{a}}\right)$, the experiments were performed using either, a divided or undivided electrochemical cell. Using the undivided cell, the setup was the one described in subsection 2.3. A solution of $22 \mathrm{~mL}$ of $0.5 \mathrm{M} \mathrm{H}_{2} \mathrm{SO}_{4}$ was electrolyzed at $25^{\circ} \mathrm{C}$ and $j=8 \mathrm{~mA} \mathrm{~cm}^{-2}$, with constant stirring at $6 \mathrm{rpm}$, for $60 \mathrm{~min}$. The geometrically active area of the two carbon steel plates used as the anode and cathode (pre-treated as explained above), with an interelectrode gap of 0.7 $\mathrm{cm}$, was $2.40 \mathrm{~cm}^{-2}$. Coumarin at a concentration of $0.5 \mathrm{mM}$ was used as probe compound to detect ${ }^{\bullet} \mathrm{OH}_{\mathrm{a}}$. The decrease in its absorbance was analyzed by UV-Vis, in the absence and presence of $t-\mathrm{BuOH}$ as radical scavenger. Using the divided cell, the electrolyses were performed using a salt bridge, with $0.5 \mathrm{M} \mathrm{H}_{2} \mathrm{SO}_{4}+0.5 \mathrm{mM}$ coumarin as the anolyte and 0.5 $\mathrm{M} \mathrm{H}_{2} \mathrm{SO}_{4}$ as the catholyte, or viceversa. The electrochemical cell replaced the one shown in Fig. 1.

In order to demonstrate the potential production of hydroxyl radicals via photoelectrochemical route $\left({ }^{\bullet} \mathrm{OH}_{\mathrm{ph}}\right)$ and show their impact on the EC treatment of the wastewater, a two step procedure was followed: (i) first, real wastewater was electrolyzed as commented in subsection 2.3 and then filtered; (ii) then, the resulting sample was put in contact with $0.5 \mathrm{mM}$ coumarin, and the mixture was irradiated with light $(\lambda=254$ and 365 $\mathrm{nm})$. Comparative analyses of ${ }^{\bullet} \mathrm{OH}$ ph were performed by using a different method as first step, namely EO using a $\mathrm{Ti} \mid \mathrm{IrO}_{2}-\mathrm{Ta}_{2} \mathrm{O}_{5}$ anode (provided by CIDETEQ). Such tests were performed at $j=40 \mathrm{~mA} \mathrm{~cm}^{-2}$ and, owing to the low ${ }^{\bullet} \mathrm{OH}$ production, the $0.5 \mathrm{mM}$ coumarin solution was placed directly in the electrolysis cell. The resulting solution was irradiated at 
different time intervals from 0 to $100 \mathrm{~min}$. The characterization and activation of Ti|IrO $\mathrm{I}_{2}-$ $\mathrm{TaO}_{5}$ has been previously reported [27].

\section{Results and discussion}

\subsection{Influence of current density in EC treatment of car wash wastewater}

Table 3 shows the change of main physicochemical parameters obtained upon EC treatment of raw wastewater at different current densities $\left(j=3,7,8,9\right.$ and $\left.10 \mathrm{~mA} \mathrm{~cm}^{-2}\right)$ for $15 \mathrm{~min}$. As can be seen, globally, the largest removals were achieved at $j=8 \mathrm{~mA} \mathrm{~cm}{ }^{-2}$, with TSS, turbidity, and color decays of 98.7\%, 98.3\% and 93.1\%, respectively. Lower removals were attained for IC (20.4\%), TN (0.7\%) and TOC (27.9\%). It is important to mention that the positive ORP value became higher in all trials, suggesting the production of oxidizing agents. At $j<8 \mathrm{~mA} \mathrm{~cm}^{-2}$, TOC abatement was quite low, only reaching $10.6 \%$ as maximum. At $\mathrm{j}>8 \mathrm{~mA} \mathrm{~cm}{ }^{-2}$, TOC removal percentages were greater, up to $36.2 \%$, but lower removals of TSS, turbidity and color were achieved.

It is important to keep in mind that at a car wash, large amounts of detergents and soaps are used, which mix with humic substances (HS) mainly attached to tires. It is thus logical to presuppose that these kinds of organic components account for a substantial TOC fraction not removed by EC at each $j$. To demonstrate this, samples withdrawn at different times were analyzed by fluorescence spectroscopy along all the EC treatments prolonged for 15 min. Fig. 3a shows the initial fluorescence spectrum and those obtained after 15 min at each $j$. The spectra are characteristic of HS [28], as also verified by means of HS extractions from a soil sample, which yielded the same fluorescence pattern as that shown. At the optimum $j=8 \mathrm{~mA} \mathrm{~cm}{ }^{-2}$, a large part of the humic matter was removed but total 
disappearance was not achieved, as depicted in Fig. 3b. The time course of main parameters like TSS, turbidity, color and TOC in EC at that optimal $j$ is shown in Fig. 3c, where the slow decay of TOC as compared to the other parameters is evidenced. The UV-Vis spectra at time zero and after 15 min of EC treatment at the same $j$ are compared in Fig. 3d. In agreement with TOC analysis, it is clearly observed from the bands that organic matter cannot be completely eliminated. Worth noting, the characteristic band usually associated to hypochlorite formation $(\lambda=300 \mathrm{~nm})$ [29] was not detected. Finally, Fig. 3e shows the time course of the cell voltage during the EC treatments at all $j$ values. The voltage remained quite stable between 3 an $5 \mathrm{~V}$, with only a slight rising trend, except at $10 \mathrm{~mA}$ $\mathrm{cm}^{-2}$. The low voltage, below $2 \mathrm{~V}$, may be attributed to a lower passivation of the electrodes along with a slightly higher electrical conductivity from the greater $\mathrm{Fe}^{2+}$ release.

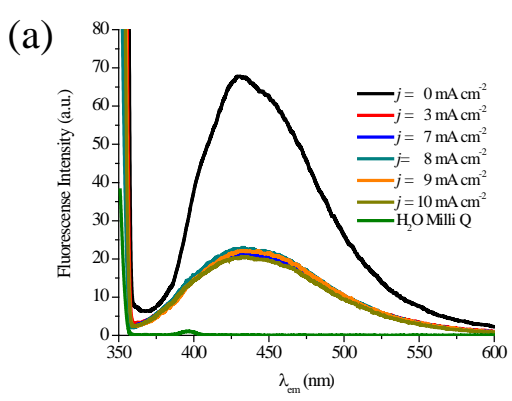

(d)

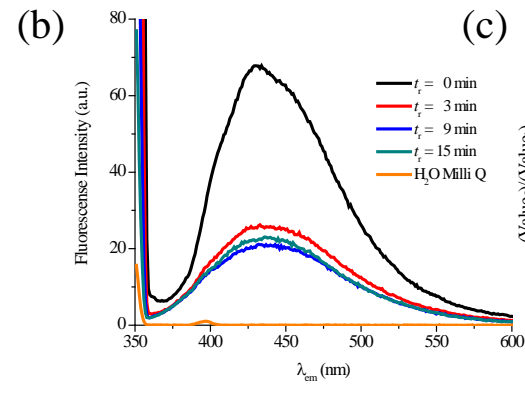

(e)
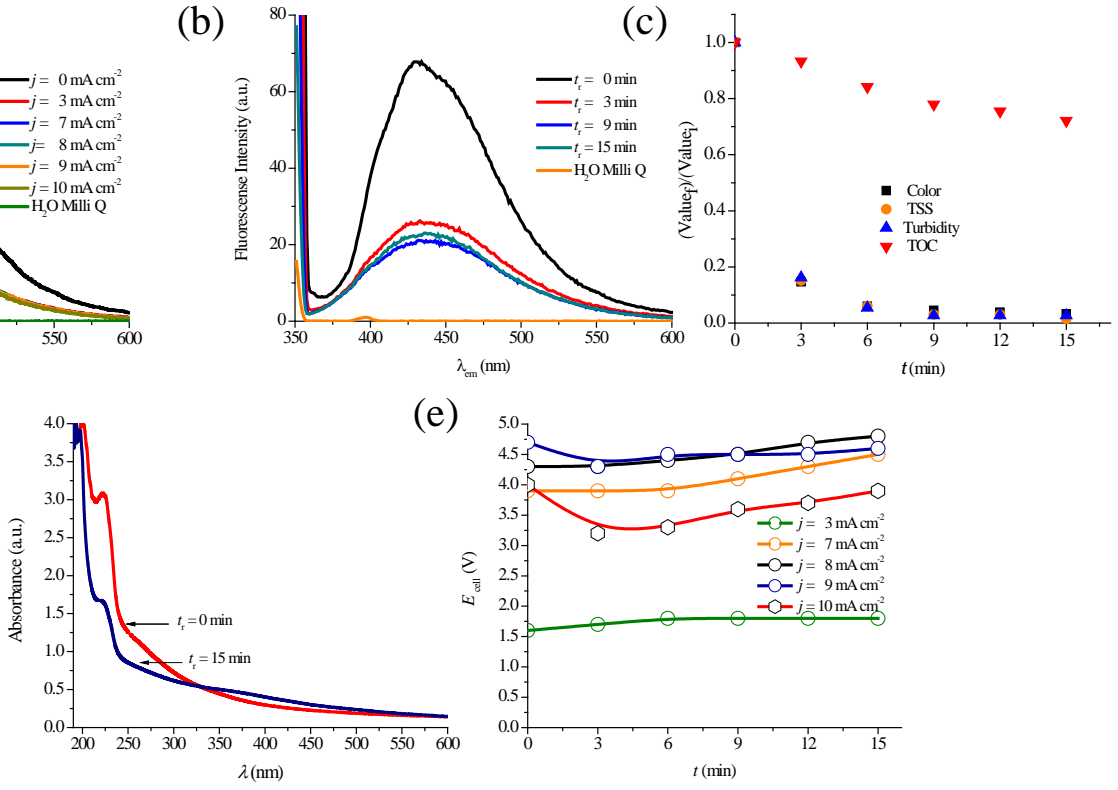

Fig. 3. Analysis of physicochemical parameters during the EC treatment of raw car wash wastewater at natural $\mathrm{pH} 8.4$ and $25{ }^{\circ} \mathrm{C}$ using an undivided cell for $15 \mathrm{~min}$. In (a), fluorescence spectra at 0 and 15 min, at different $j$ values; in (b-d), time course of different parameters in EC at $j=8 \mathrm{~mA} \mathrm{~cm}^{-2}$; in (e) variation of cell voltage with time, at all $j$. 


\subsection{Analysis of ${ }^{\bullet} \mathrm{OH}_{a}$ during electrocoagulation}

Considering the low $\eta\left(\mathrm{O}_{2}\right)$ of Fe-based anodes, one could presuppose a poor production of ${ }^{\bullet} \mathrm{OH}_{\mathrm{a}}$ and, therefore, a rather minor role of ${ }^{\bullet} \mathrm{OH}$-mediated oxidation to TOC removal in EC treatment. Although this seems reasonable, the literature tends to be confusing since the potential role of ${ }^{\bullet} \mathrm{OH}_{\mathrm{a}}$ is still hypothesized [13]. In order to confirm or discard this possibility, different electrolyses were conducted in the presence of $0.5 \mathrm{mM}$ coumarin as probe using both, undivided and divided cells. The latter was made to rule out the participation of hydroxyl radical generated through cathodic reduction $\left({ }^{\bullet} \mathrm{OH}_{\mathrm{c}}\right)$ [30]:

$\mathrm{O}_{2}+2 \mathrm{H}^{+}+3 \mathrm{e}^{-} \rightarrow \cdot \mathrm{OH}_{\mathrm{c}}+\mathrm{OH}^{-}$

The samples were analyzed by UV-Vis spectroscopy to monitor the disappearance of coumarin, in the absence or presence of $t$ - $\mathrm{BuOH}$ as radical scavenger [31].

Fig. 4 shows the UV-Vis spectra obtained before and after the EC treatment in the undivided cell. In the presence of ${ }^{\bullet} \mathrm{OH}$, coumarin reacts according to reaction (14) with $k=$ $\left.2 \times 10^{9} \mathrm{M}^{-1} \mathrm{~s}^{-1}\right)$ [32], resulting in the formation of the fluorescent compound 7hydroxycoumarin, as follows:

$\mathrm{C}_{9} \mathrm{H}_{6} \mathrm{O}_{2}+2 \cdot \mathrm{OH} \rightarrow \mathrm{C}_{9} \mathrm{H}_{6} \mathrm{O}_{3}+\mathrm{H}_{2} \mathrm{O}$

It can be observed that the initial absorbance was quite stable during the electrolysis, which means that ${ }^{\bullet} \mathrm{OH}_{\mathrm{a}}$ is not produced at a significant concentration. The results from fluorescence spectroscopy confirmed the sole presence of coumarin, which exhibited a sharp emission peak $393 \mathrm{~nm}$. [33]. The trial made with addition of $t-\mathrm{BuOH}$, a known ${ }^{\bullet} \mathrm{OH}$ scavenger with $k=6 \times 10^{8} \mathrm{M}^{-1} \mathrm{~s}^{-1}$ that promotes multiple competing reactions [34, 35-38], confirmed the stability of coumarin. It can then be concluded that ${ }^{\bullet} \mathrm{OH}_{\mathrm{a}}$ does not 
participates to yield the $27.9 \%$ of TOC removal at $j=8 \mathrm{~mA} \mathrm{~cm}^{-2}$ (Fig. 3c). It is important to mention that these analyses were performed in duplicate, using a quartz flow cell [39], taking special care when drying it.

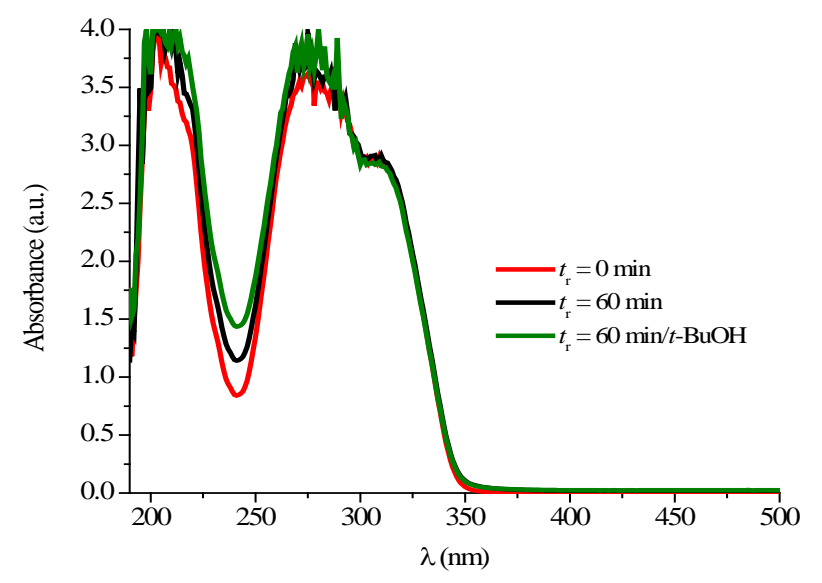

Fig. 4. Analysis of ${ }^{\bullet} \mathrm{OH}_{\mathrm{a}}$ from the evolution of $\mathrm{UV}$-Vis spectra of coumarin. A solution of $22 \mathrm{~mL}$ containing $0.5 \mathrm{M} \mathrm{H}_{2} \mathrm{SO}_{4}+0.5 \mathrm{mM}$ coumarin was electrolyzed in an undivided cell under EC conditions, at $25{ }^{\circ} \mathrm{C}$ and $j=8 \mathrm{~mA} \mathrm{~cm}{ }^{-2}$, with constant stirring at $6 \mathrm{rpm}$ for $60 \mathrm{~min}$ in the absence or presence of $0.050 \mathrm{M} t$-BuOH. The geometrical area of the two carbon steel plates used as the anode and cathode was $2.40 \mathrm{~cm}^{-2}$.

To confirm the results, the analysis was also carried out in a divided cell, using a salt bridge (agar, $3 \mathrm{M} \mathrm{KCl}$ ). The $0.5 \mathrm{M} \mathrm{H}_{2} \mathrm{SO}_{4}+0.5 \mathrm{mM}$ coumarin mixture was employed as the anolyte and $0.5 \mathrm{M} \mathrm{H}_{2} \mathrm{SO}_{4}$ as catholyte. As shown in Fig. 5a, no significant change in the UV-Vis spectrum was registered. The same kind of trial but exchanging the anolyte and catholyte was further made to test the possible production of ${ }^{\bullet} \mathrm{OH}_{\mathrm{c}}$ from reaction (13). Fig. 5b compares the spectra before and after the electrolysis, showing no difference. 
In conclusion, in typical EC treatments, the formation of hydroxyl radicals at the anode or cathode surface can be disregarded. However, the contribution of indirect oxidation processes in the bulk cannot be still ruled out.
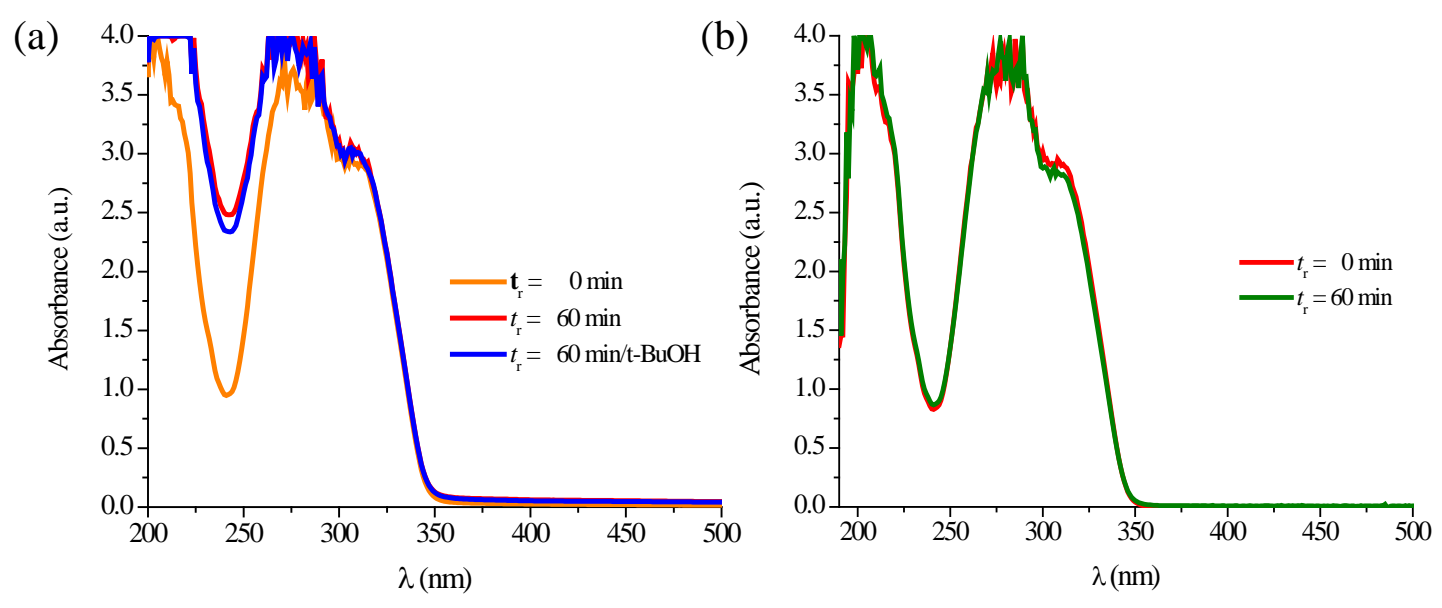

Fig. 5. Analysis of (a) ${ }^{\bullet} \mathrm{OH}_{\mathrm{a}}$ and (b) ${ }^{\bullet} \mathrm{OH}_{\mathrm{c}}$ from the evolution of UV-Vis spectra of coumarin. The experiments were performed as described in Fig. 4, but using a divided cell, with $0.5 \mathrm{M} \mathrm{H}_{2} \mathrm{SO}_{4}+0.5 \mathrm{mM}$ coumarin as (a) anolyte or (b) catholyte.

\subsection{Effect of experimental parameters on the in-situ generation of active chlorine}

Fig. 6 shows the effect of $\mathrm{pH}\left(7.0\right.$ and natural $\mathrm{pH}$ 8.4), ionic content $\left(\mathrm{SO}_{4}{ }^{2-}\right.$ and $\left.\mathrm{Cl}^{-}\right)$ and UVC light $(\lambda=254 \mathrm{~nm})$ on the TOC decay obtained during the EC treatment of the real wastewater using an undivided cell, at $25^{\circ} \mathrm{C}$ and $j=8 \mathrm{~mA} \mathrm{~cm}{ }^{-2}$. The adjustment of $\mathrm{pH}$ to 7 was made by adding either $\mathrm{H}_{2} \mathrm{SO}_{4}$ or $\mathrm{HCl}$, in order to simultaneously assess the influence of both anions, which were identified as most abundant (Table 2). In the case of $\mathrm{Cl}^{-}$anion, the potential production of active chlorine could serve as a source of hydroxyl radicals upon irradiation, as described in reactions (7) and (8). 


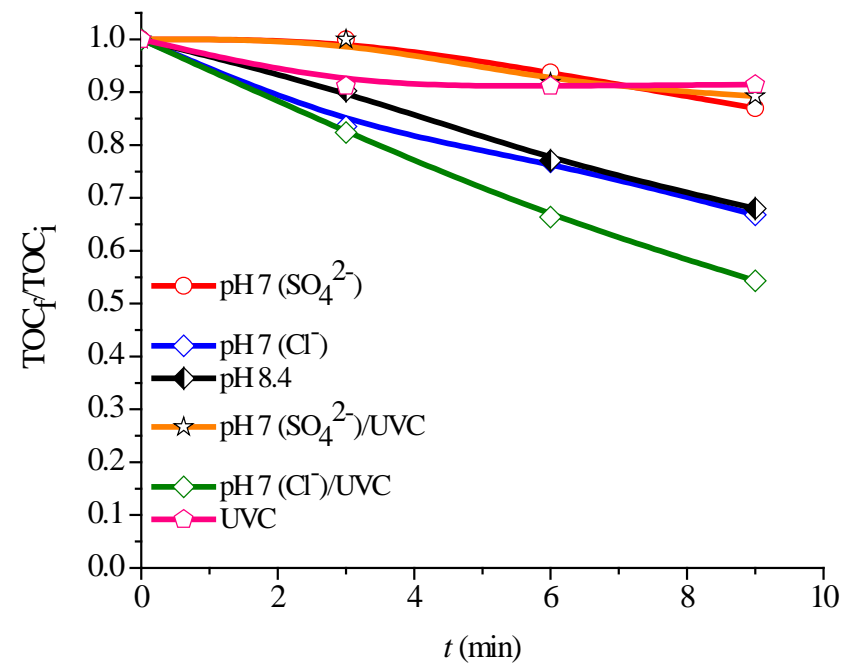

Fig. 6. Effect of $\mathrm{pH}$, ionic content $\left(\mathrm{SO}_{4}{ }^{2-}\right.$ and $\left.\mathrm{Cl}^{-}\right)$and irradiation with UVC light $(\lambda=254$ $\mathrm{nm}$ ) on normalized TOC decay during the EC treatment of raw car wash wastewater using an undivided cell, at $25^{\circ} \mathrm{C}$ and $j=8 \mathrm{~mA} \mathrm{~cm}^{-2}$.

As can be seen, EC treatment at $\mathrm{pH} 7.0$ upon $\mathrm{pH}$ adjustment with $\mathrm{H}_{2} \mathrm{SO}_{4}$ led to poorer TOC removal as compared to EC at natural $\mathrm{pH}$ 8.4, which can be explained by the lower stability of the insoluble $\mathrm{Fe}(\mathrm{OH})_{2}$ and $\mathrm{Fe}(\mathrm{OH})_{3}$ species and hence, the more difficult aggregation and precipitation of organic matter to finally become coagulated. In contrast, the use of $\mathrm{HCl}$ to adjust the solution $\mathrm{pH}$ to 7.0 was very positive, yielding almost the same profile for TOC abatement as compared to $\mathrm{pH}$ 8.4. The addition of $\mathrm{Cl}^{-}$anion is then beneficial, which can be attributed to the production of active chlorine mainly in the form of $\mathrm{ClO}^{-}$, resulting in a mediated oxidation process. After that, the effect of solution irradiation with UVC light $(\lambda=254 \mathrm{~nm})$ on TOC removal was investigated. As shown in Fig. 6, photolysis did not cause significant changes, only reaching 5\% TOC decay. The turbidity caused by TSS in the raw wastewater is thus responsible for the poor light penetration into the solution bulk, being quite difficult to cause the cleavage of benzenic 
rings of aromatic contaminants. Irradiation of the sample prepared at $\mathrm{pH} 7.0$ with $\mathrm{H}_{2} \mathrm{SO}_{4}$ had also no effect on TOC abatement, attaining less than $15 \%$ as in the dark. Conversely, a greater TOC removal of $45 \%$ was obtained when $\mathrm{HCl}$ was used to adjust the $\mathrm{pH}$ to 7.0 . Such enhancement could be due to the photoinduced formation of hydroxyl radical in the bulk $\left({ }^{\bullet} \mathrm{OH}_{\mathrm{ph}}\right)$ from reactions (7) and (8). Since this is of great interest, considering that most industrial effluents possess a high content of chlorides, next subsection is focused on the indirect determination of such radicals.

\subsection{Assessment of ${ }^{\bullet} \mathrm{OH}$ ph production during electrocoagulation}

To investigate the photochemical formation of homogeneous hydroxyl radical from active chlorine activation, a set of electrolyses was carried out with a solution of $0.5 \mathrm{mM}$ coumarin at different $\mathrm{pH}$ values (adjusted with $\mathrm{HCl}$ ), at $j=8 \mathrm{~mA} \mathrm{~cm}{ }^{-2}$ for $60 \mathrm{~min}$. The samples were immediately exposed to UVA $(\lambda=365 \mathrm{~nm})$ or UVC $(\lambda=254 \mathrm{~nm})$ irradiation. As can be observed in Fig. 7, no significant change of the UV-Vis spectrum of coumarin was detected along these trials. The apparent absence of ${ }^{\bullet} \mathrm{OH}_{\mathrm{ph}}$ during EC can then be explained by an excessively low accumulation of active chlorine, thus preventing its subsequent photodecomposition according to reaction (7). As commented from Fig. 6, UVC irradiation has an evident positive effect on TOC removal, which now can be explained according to the following sequence of events: (i) active chlorine is formed from $\mathrm{Cl}^{-}$oxidation at the anode surface, (ii) some organic compounds become oxidized to byproducts, and (iii) some of these by-products are more easy to coagulate (see Fig. 6, pH 7.0 with $\mathrm{Cl}^{-}$), and/or are phototransformed by UVC light to other compounds, whose coagulation is finally enhanced. 

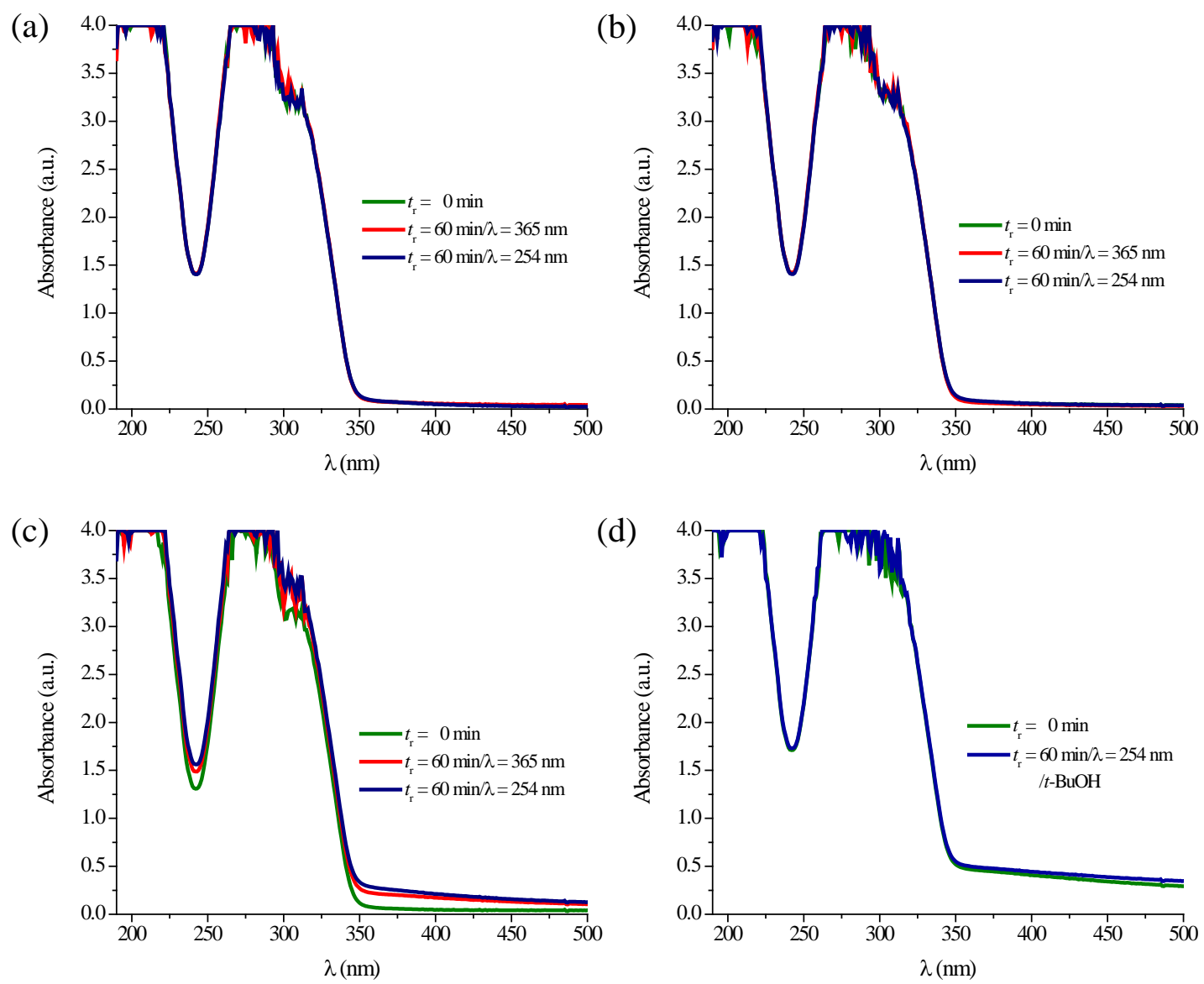

Fig. 7. Assessment of ${ }^{\bullet} \mathrm{OH}_{\mathrm{ph}}$ production during the EC treatments under UVA $(\lambda=365 \mathrm{~nm})$ or UVC light $(\lambda=254 \mathrm{~nm})$ irradiation. For this, a solution of $22 \mathrm{~mL}$ containing $0.5 \mathrm{mM}$ coumarin was electrolyzed under conditions described in Fig. 4, at (a) natural pH 8.4, (b) $\mathrm{pH} 7.0$, (c) pH 3.0, and (d) pH 3.0 with $0.050 \mathrm{M}$ t-BuOH.

\subsection{Electro-oxidation with an $\mathrm{IrO}_{2}-\mathrm{Ta}_{2} \mathrm{O}_{5}$ anode}

According to the results obtained for EC, and to demonstrate the potential use of active chlorine photoactivation with UV light to form ${ }^{\bullet} \mathrm{OH}_{\mathrm{ph}}, 70 \mathrm{~mL}$ of real wastewater samples were electrolyzed by $\mathrm{EO}$ at natural $\mathrm{pH} 8.4$ and at $\mathrm{pH} 7.0$ and 3.0 (adjusted with $\mathrm{HCl}$ ). $\mathrm{Ti} \mid \mathrm{IrO}_{2}-\mathrm{Ta}_{2} \mathrm{O}_{5}$ and stainless steel were used as the anode and cathode, respectively, operating at $j=40 \mathrm{mAcm}^{-2}$ for $60 \mathrm{~min}$. The electrolyzed solutions were filtered, mixed with 
$0.5 \mathrm{mM}$ coumarin and exposed to UV irradiation (365 and $254 \mathrm{~nm}$ ), yielding the UV-Vis spectra shown in Fig. 8 for coumarin.
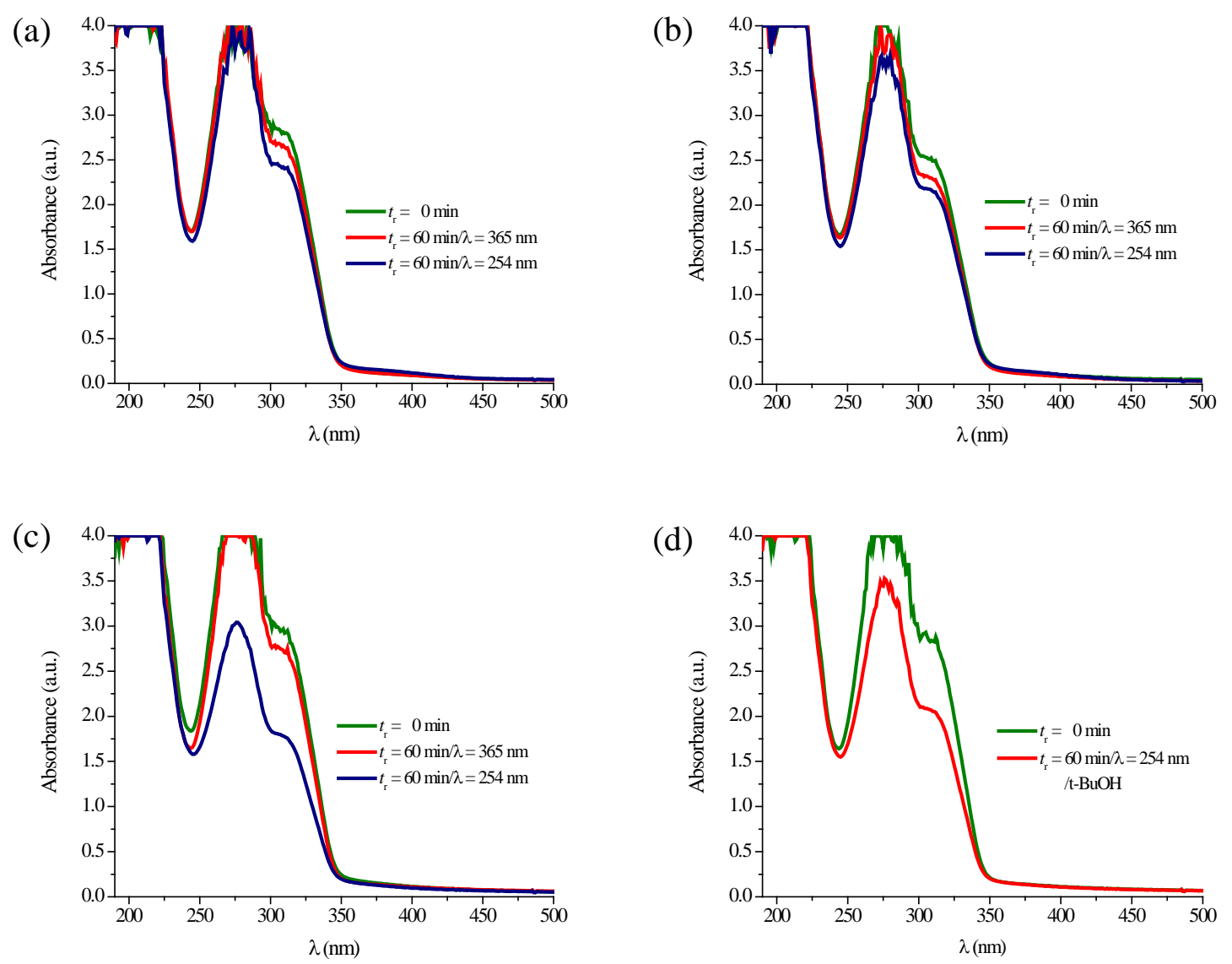

Fig. 8. Assessment of $\bullet^{\bullet} \mathrm{OH}_{\mathrm{ph}}$ produced upon photoactivation of active chlorine pregenerated by EO process. First, solutions of $70 \mathrm{~mL}$ of car wash wastewater were treated by EO with a Ti| $\mid \mathrm{IrO}_{2}-\mathrm{Ta}_{2} \mathrm{O}_{5}$ anode at $j=40 \mathrm{mAcm}^{-2}$ for $60 \mathrm{~min}$. The resulting solution was mixed with $0.5 \mathrm{mM}$ coumarin and irradiated with UVA $(\lambda=365 \mathrm{~nm})$ or UVC light $(\lambda=$ $254 \mathrm{~nm}$ ). The EO process was applied at (a) natural pH 8.4, (b) $\mathrm{pH} 7.0$, (c) pH 3.0, and (d) pH 3.0 with $0.050 \mathrm{M} \mathrm{t-BuOH}$.

At all $\mathrm{pH}$ values, irradiation with UVA light $(\lambda=365 \mathrm{~nm})$ only caused a slight decrease in absorbance (Fig. 8a-c). In contrast, the absorbance decays were much more evident using UVC light at $\lambda=254 \mathrm{~nm}$, which was especially remarkable at pH 3.0 (Fig. 
8c). This great effect of UVC light could be directly associated to coumarin oxidation by ${ }^{-} \mathrm{OH}_{\mathrm{ph}}$ according to reactions (7) and (8). To demonstrate this, the trial at $\mathrm{pH} 3.0$ was repeated using $t-\mathrm{BuOH}$ during the irradiation step. The results shown in Fig. 8d reveal a much smaller change of coumarin absorbance as compared to time zero, confirming a scavenging effect on ${ }^{\bullet} \mathrm{OH}_{\mathrm{ph}}$. All these analyses were performed in duplicate. Although the results discussed above suggest that, under the conditions evaluated, ${ }^{\bullet} \mathrm{OH}_{\mathrm{a}}$ and ${ }^{\bullet} \mathrm{OH}_{\mathrm{ph}}$ are not generated in EC treatments, coupling with EO process may be of interest to induce the formation of ${ }^{\bullet} \mathrm{OH}_{\mathrm{ph}}$ under UVC irradiation.

To confirm the evidence of Fig. 8, Fig. 9 shows the results from UV-Vis analysis and fluorescence spectroscopy obtained upon EO treatment of $0.5 \mathrm{M} \mathrm{HCl}+0.5 \mathrm{mM}$ coumarin with a Ti $\mid \mathrm{IrO}_{2}-\mathrm{Ta}_{2} \mathrm{O}_{5}$ anode at $j=40 \mathrm{~mA} \mathrm{~cm}{ }^{-2}$, photoassisted with UVC light for $100 \mathrm{~min}$.
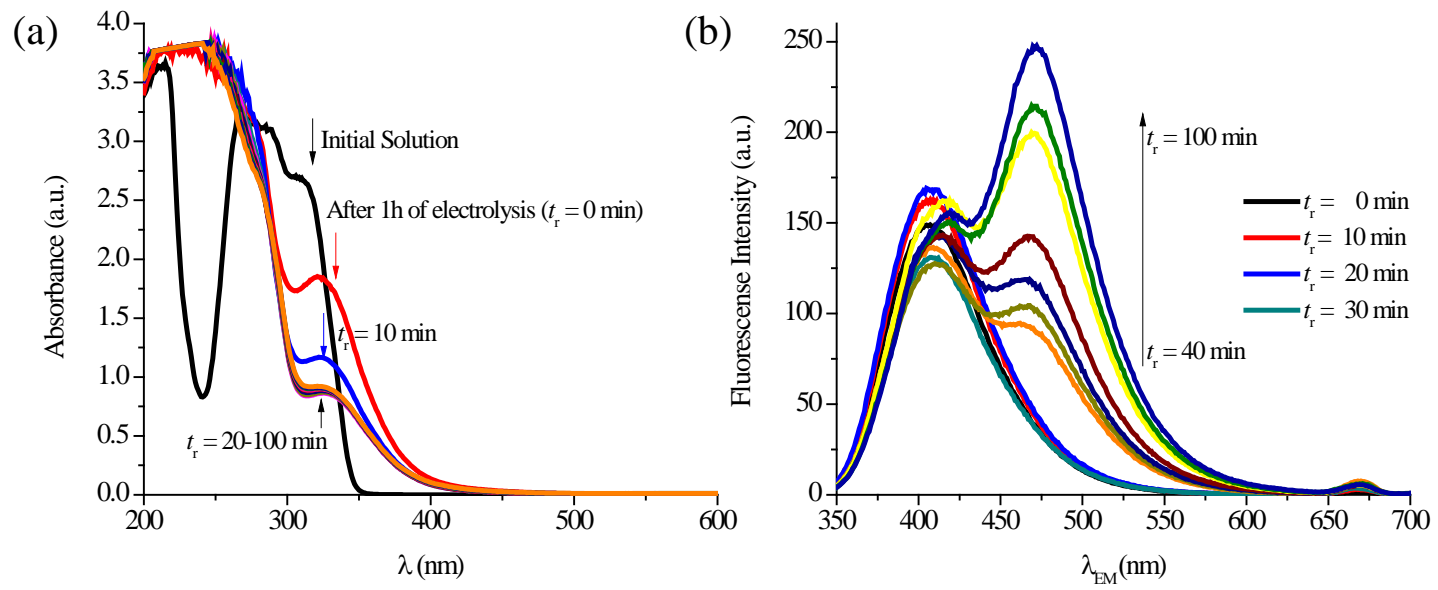

Fig. 9. Analysis of ${ }^{\bullet} \mathrm{OH}_{\mathrm{ph}}$, produced using EO with $\mathrm{Ti} \mid \mathrm{IrO}_{2}-\mathrm{Ta}_{2} \mathrm{O}_{5}$ photoassisted with UVC irradiation, from the evolution of (a) UV-Vis spectra of coumarin an (b) fluorescence spectra of 7-hydroxycoumarin. Conditions were similar to those of Fig. 8, but employing a solution with $0.5 \mathrm{M} \mathrm{HCl}+0.5 \mathrm{mM}$ coumarin. 
A significant decrease of coumarin absorbance can be seen in Fig. 9a, which occurs in concomitance with 7-hydroxycoumarin accumulation $\left(\lambda_{E m}=490 \mathrm{~nm}\right.$, Fig. 9b). The appearance of the hydroxylated product upon action of ${ }^{\bullet} \mathrm{OH}$ ph was only evident at times longer than $40 \mathrm{~min}$.

\section{Conclusions}

The treatment of raw car wash wastewater by EC process with carbon steel electrodes has been proven very effective to remove more than $98 \%$ of TSS and turbidity, along with 93.1\% of color in $15 \mathrm{~min}$ at $8 \mathrm{~mA} \mathrm{~cm}^{-2}$, although a low TOC abatement of $27.9 \%$ was achieved. The study has revealed that significant concentrations of ${ }^{\bullet} \mathrm{OH}_{\mathrm{a}}$ and ${ }^{\bullet} \mathrm{OH}_{\mathrm{ph}}$ are not attained during an EC treatment and hence, TOC removal can only be associated to oxidation mediated by active chlorine and coagulation with $\mathrm{Fe}(\mathrm{OH})_{\mathrm{n}}$. In contrast, the production of ${ }^{\bullet} \mathrm{OH}_{\mathrm{ph}}$ has been demonstrated in EO treatment of the same wastewater with a $\mathrm{Ti} \mid \mathrm{IrO}_{2}-\mathrm{Ta}_{2} \mathrm{O}_{5}$ anode, with photoassistance from a UVC lamp that promotes the photodecomposition of active chlorine.

\section{Acknowledgements}

The authors would like to thank Mexico’s National Council of Science and Technology (CONACyT) for its financial support of this research. Funding from project CTQ201678616-R (AEI/FEDER, EU) is also acknowledged. The authors also thank Alejandra Rojo for her review of this manuscript. 


\section{References}

[1] S.A. Kiran, G. Arthanareeswaran, Y.L. Thuyavan, A.F. Ismail, Influence of bentonite in polymer membranes for effective treatment of carwash effluent to protect the ecosystem, Ecotoxicol. Environ. Saf. 121 (2015) 186-192.

[2] I.A. Rodriguez Boluarte, M. Andersen, B.K. Pramanik, C.-Y. Chang, S. Bagshaw, L. Farago, V.h Jegatheesan, L. Shu, Reuse of car wash wastewater by chemical coagulation and membrane bioreactor treatment processes, Int. Biodeterior. Biodegrad. 13 (2016) 44-48.

[3] Z. Qamar, S. Khan, A. Khan, M. Aamir, J. Nawab, M. Waqas, Appraisement, source apportionment and health risk of polycyclic aromatic hydrocarbons (PAHs) in vehiclewash wastewater, Pakistan, Sci. Total Environ. 605-606 (2017) 106-113.

[4] M. Panizza, G. Cerisola, Applicability of electrochemical methods to carwash wastewaters for reuse. Part 1: Anodic oxidation with diamond and lead dioxide anodes, J. Electroanal. Chem. 638 (2010) 28-32.

[5] Z.A. Bhatti, Q. Mahmood, I.A. Raja, A.H. Malik, M.S. Khan, D. Wu, Chemical oxidation of carwash industry wastewater as an effort to decrease water pollution, Phys. Chem. Earth 36 (2011) 465-469.

[6] W.J. Lau, A.F. Ismail, S. Firdaus, Car wash industry in Malaysia: Treatment of car wash effluent using ultrafiltration and nanofiltration membranes, Sep. Purif. Technol. 104 (2013) 26-31.

[7] M. Panizza, G. Cerisola, Applicability of electrochemical methods to carwash wastewaters for reuse. Part 2: Electrocoagulation and anodic oxidation integrated process, J. Electroanal. Chem. 638 (2010) 236-240. 
[8] R. Zaneti, R. Etchepare, J. Rubio, Car wash wastewater reclamation. Full-scale application and upcoming features, Resour. Conserv. Recycl. 55 (2011) 953-959.

[9] R. Etchepare, R. Zaneti, A. Azevedo, J. Rubio, Application of flocculation-flotation followed by ozonation in vehicle wash wastewater treatment/disinfection and water reclamation, Desalin. Water Treat. (2014) 1-9.

[10] A.C.S. Pinto, L. de Barros Grossi, R.A.C. de Melo, T.M. de Assis, V.M. Ribeiro, M.C.S. Amaral, K.C. de Souza Figueiredo, Carwash wastewater treatment by micro and ultrafiltration membranes: Effects of geometry, pore size, pressure difference and feed flow rate in transport properties, J. Water Process Eng. 17 (2017) 143-148.

[11] Y. Meas, J.A. Ramirez, M.A. Villalon, T.W. Chapman, Industrial wastewaters treated by electrocoagulation, Electrochim. Acta 55 (2010) 8165-8171.

[12] F. Ilhan, U. Kurt, O. Apaydin, M.T. Gonullu, Treatment of leachate by electrocoagulation using aluminum and iron electrodes, J. Hazard. Mater. 154 (2008) 381-389.

[13] D. Ghernaout, Advanced oxidation phenomena in electrocoagulation process: a myth or reality?, Desalin. Water Treat. 51 (2013) 7536-7554.

[14] E. Bocos, E. Brillas, M.A. Sanromán, I. Sirés, Electrocoagulation: Simply a phase separation technology? The case of bronopol compared to its treatment by EAOPs, Environ. Sci. Technol. 50 (2016) 7679-7686.

[15] N. Kishimoto, Y. Nakamura, M. Kato, H. Otsu, Effect of oxidation-reduction potential on an electrochemical Fenton-type process, Chem. Eng. J. 260 (2015) 590-595.

[16] Z.G. Aguilar, E. Brillas, M. Salazar, J.L. Nava, I. Sirés, Evidence of Fenton-like reaction with active chlorine during the electrocatalytic oxidation of Acid Yellow 36 azo dye 
with Ir-Sn-Sb oxide anode in the presence of iron, Appl. Catal. B: Environ. 206 (2017) $44-52$.

[17] S. Cotillas, P. Cañizares, M.J. Martín de Vidales, C. Sáez, M.A. Rodrigo, J. Llanos, Electrocoagulation-UV irradiation process for urban wastewater reuse, Chem. Eng. Trans. 41 (2014) 133-138.

[18] D. Wang, J. R. Bolton, R. Hofmann, Medium pressure UV combined with chlorine advanced oxidation for trichloroethylene destruction in a model water, Water Res. 46 (2012) 4677-4686.

[19] P.Y. Chan, M.G. El-Din, J.R. Bolton, A solar-driven UV/Chlorine advanced oxidation process, Water Res. 46 (2012) 5672-5682.

[20] M.A. Tony, P.J. Purcell, Y.Q. Zhao, A.M. Tayeb, M.F. El-Sherbiny, Photo-catalytic degradation of an oil-water emulsion using the photo-fenton treatment process: Effects and statistical optimization, J. Environ. Sci. Health Part A 44 (2009) 179-187.

[21] M.A. Tony, Z. Bedri, Experimental design of photo-Fenton reactions for the treatment of car wash wastewater effluents by response surface methodological analysis, Adv. Environ. Chem. 2014 (2014) 1-8.

[22] Z.B. Gönder, G. Balcıoglu, I. Vergili, Y. Kaya, Electrochemical treatment of carwash wastewater using $\mathrm{Fe}$ and $\mathrm{Al}$ electrode: Techno-economic analysis and sludge characterization, J. Environ. Manage. 200 (2017) 380-390.

[23] M.J. Mohammadi, A. Takdastan, S. Jorfi, A. Neisi, M. Farhadi, A.R. Yari, S. Dobaradaran, Y.O. Khaniabadi, Electrocoagulation process to Chemical and Biological Oxygen Demand treatment from carwash grey water in Ahvaz megacity, Iran, Data Brief 11 (2017) 634-639. 
[24] H. Rubí-Juárez, C. Barrera-Díaz, I. Linares-Hernández, C. Fall, B. Bilyeu, A combined electrocoagulation-electrooxidation process for carwash wastewater reclamation, Int. J. Electrochem. Sci. 10 (2015) 6754-6767.

[25] Official Mexican Regulation NOM-001-SEMARNAT-1996, Maximum limits allowed of pollutants in discharges of wastewaters and national resources.

[26] M.O. Azzam, Y. Tahboub, M. Al-Tarazi, Effect of counter electrode material on the anodic destruction of 4-Cl phenol solution, Process Saf. Environ. Prot. 77 (1999) 219226.

[27] A. Medel, E. Méndez, J.L. Hernández-López, J.A. Ramírez, J. Cárdenas, R.F. Frausto, L. A. Godínez, E. Bustos, Y. Meas, Novel electrochemical treatment of spent caustic from the hydrocarbon industry using Ti/BDD, Int. J. Photoenergy 2015 (2015) 1-18.

[28] D.L. Gone, J.-L. Seidel, C. Batiot, K. Bamory, R. Ligban, J. Biemi, Using fluorescence spectroscopy EEM to evaluate the efficiency of organic matter removal during coagulation-flocculation of a tropical surface water (Agbo reservoir), J. Hazard. Mater. 172 (2009) 693-699.

[29] M. Santhanam, S. Annamalai, S. Sudanthiramoorthy, R. Gopalakrishnan, A simple strategy for monitoring of aromatic degradation in a chloride mediated electrooxidation process, RSC Adv. 5 (2015) 75528-75532.

[30] J.-M. Noël, A. Latus, C. Lagrost, E. Volanschi, P. Hapiot, Evidence for OH radical production during electrocatalysis of oxygen reduction on Pt surfaces: Consequences and application, J. Am. Chem.Soc. 134 (2012) 2835-2841.

[31] R.A. Herrada, A. Medel, F. Manríquez, I. Sirés, E. Bustos, Preparation of $\mathrm{IrO}_{2}-\mathrm{Ta}_{2} \mathrm{O}_{5} \mid \mathrm{Ti}$ 
electrodes by immersion, painting and electrophoretic deposition for the electrochemical removal of hydrocarbons from water, J. Hazard. Mater 319 (2016) 102-110.

[32] Y. Nosaka, K. Ohtaka, N. Ohguri, A. Y. Nosaka, Detection of OH radicals generated in polymer electrolyte membranes of fuel cells, J. Electrochem. Soc. 158 (2011) B430B433.

[33] R. M. Félix-Navarro, M. I. Salazar-Gastélum, M. Beltrán-Gastélum, E. Reynoso-Soto, SW. Lin, S. Pérez-Sicairos, F. Paraguay-Delgado, G. Alonso-Núñez, Development of a Pt-Ir bimetallic nanoparticulated electrocatalyst deposited on MWCNT for an electroFenton process, J. Electrochem. Soc. 161 (2014) H845-H853.

[34] B. de Witte, J. Dewulf, K. Demeestere, H. van Langenhove, Ozonation and advanced oxidation by the peroxone process of ciprofloxacin in water, J. Hazard. Mater. 161 (2009) 701-708.

[35] J. Muff, L.R. Bennedsen, E.G. Søgaard, Study of electrochemical bleaching of $p$ nitrosodimethylaniline and its role as hydroxyl radical probe compound, J. Appl Electrochem. 41 (2011) 599-607.

[36] A.I. Cederbaum, A. Qureshi, G. Cohen, Production of formaldehyde and acetone by hydroxyl-radical generating systems during the metabolism of tertiary butyl alcohol, Biochem. Pharmacol. 32 (1983) 3517-3524.

[37] J. Jeong, C. Kim, J. Yoon, The effect of electrode material on the generation of oxidants and microbial inactivation in the electrochemical disinfection processes, Water Res. 43 (2009) 895-901.

[38] M.E. Simonsen, J. Muff, L. R. Bennedsen, K.P. Kowalski, E.G. Søgaard, Photocatalytic bleaching of $p$-nitrosodimethylaniline and a comparison to the performance of other 
AOP technologies, J. Photochem. Photobiol. A: Chem. 216 (2010) 244-249.

[39] A. Medel, E. Bustos, L.M. Apátiga, Y. Meas, Surface activation of C-sp ${ }^{3}$ in boron-doped Diamond electrode, Electrocatalysis 4 (2013) 189-195.

[40] C.A. Martínez-Huitle, E. Brillas, Decontamination of wastewaters containing synthetic organic dyes by electrochemical methods: A general review, Appl. Catal. B: Environ. 87 (2009) 105-145. 